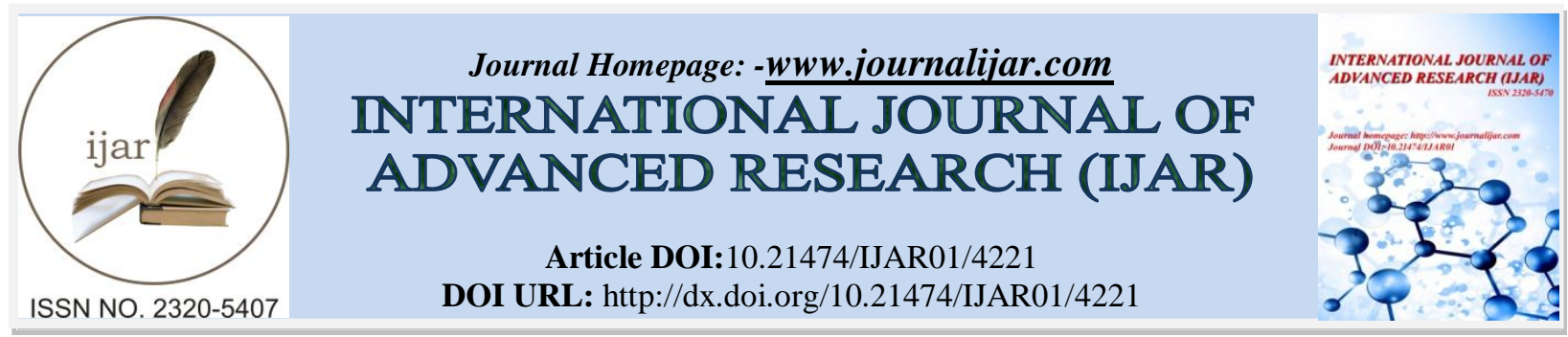

RESEARCH ARTICLE

\title{
MORPHOLOGICAL CHARACTERIZATION OF Alternaria padwickii IN RICE LEAVES (Oryza sativa L.) AND ITS PREVALENCE IN THE DEPARTMENTS OF ITAPÚA, MISIONES AND CAAZAPA.
}

\author{
Quintana $L^{1}$, Gutierrez $S^{2}$, Maidana $M^{1}$, Arriola $M^{1}$ and Ortiz $A^{1}$. \\ Facultad de Ciencias Agropecuarias y Forestales. Universidad Nacional de Itapúa, Encarnación, Paraguay. | \\ Facultad de Ciencias Agrarias. Universidad Nacional del Nordeste, Corrientes, Argentina.
}

\section{Manuscript Info}

Manuscript History

Received: 18 March 2017

Final Accepted: 21 April 2017

Published: May 2017

Key words:-

Alternaria padwickii (Trichoconiella padwickii, rice crop, foliar spot
Abstract

The climatic conditions of continuous rains and high temperatures prevailing during 2014/2015 rice crop season, due to the occurrence of the "Niño phenomenon", were very favorable for the development of fungal diseases in rice cultivation. Among pathogens that attack rice and produce foliar spots, Alternaria padwickii (Trichoconiella padwickii (Ganguly) Jain) is mentioned. This fungus also affects the grain of rice panicles, affecting the quality and seed germination. In the rice crop season 2014/2015, a high incidence of foliar spots was observed in the rice field. At this situation a phytopathological diagnosis was made in order to detect the occurrence of A. padwickii in the crop, to describe the morphological characterization of the fungus and its prevalence in the Departments of Itapúa, Misiones and Caazapá.

Copy Right, IJAR, 2017, All rights reserved.

\section{Introduction:-}

Rice (Oryza sativa L.) is one of the crops that have been increasing gradually in relation to the area destined to the production in Paraguay. In the 2013/2014 rice crop season, 120,000 h were sown (MAG, 2014), increasing to $152,000 \mathrm{~h}$ in the 2014/2015 rice crop season, with an approximate production of 800,000 t (INBIO, 2015). The cereal is mainly located in the Departments of Misiones, Itapúa and Caazapá and to a lesser extent in Paraguarí, Cordillera and other Departments of Paraguay (MAG, 2008).

The factors that have influenced basically the growth of the national production were based in the application of better technologies and the use of improved varieties (Ramírez, 2009). However, in spite of the increases in yields achieved in recent years, the massive use of these tools and climatic variations contributed to the increase of diseases incidence, especially in the 2015 harvest due to the climatic conditions of continuous rains and high temperatures prevailing during the crop season -Niño phenomenon- (Quintana et al., 2005a; Quintana et al., 2015b).

The fungus Alternaria padwicki was first identified in the United States in rice leaves and later in panicles as the cause of grain staining (Mew and González, 2002). This fungus has been recorded worldwide, mainly in rice tropical regions $(\mathrm{CAB}, 2001)$. 
This fungus mainly affects the grains of the rice paddy, which affects the quality and also the germination when sowing the infected seeds (Ou, 1985; Mew \& Misra, 1994; Mew \& Gonzales, 2002). In addition, seed incidence rates have been reported from $4 \%$ to $74.25 \%$ (Gutiérrez et al., 2010; Lovato et al., 2011; Lovato et al., 2013). It is currently one of the main pathogens associated with rice-stained grain and is also the cause of Alternaria spot in rice

Corresponding Author:-Quintana L.

Address:-Facultad de Ciencias Agropecuarias y Forestales.

s of the

on the

presence of this fungus associated with foliar rice spot, as well as the frequency of this Alternaria species in the main rice production regions of the country. In the year 2015 a high incidence of foliar spots was observed in the field, most of them characterized as oval or circular spots with a yellowish brown center and dark edges. In this situation, a phytopathological diagnosis was carried out to determine the presence of Alternaria padwickii associated to leaf spots, morphological characteristics and their prevalence in rice crops planted in the main rice producing regions in the 2014/2015 rice crop season.

\section{Materials and Methods:-}

The research was carried out in the laboratory of Microbiology of the Faculty of Sciences and Technology of the National University of Itapúa, Campus Encarnación, Paraguay.

\section{Sample Collection:-}

Field monitoring was done between January and April of 2015 year to extract rice plants samples with leaf spot symptoms, located in the Departments of Itapúa, Caazapá and Misiones, totaling 72 samples. These samples were taken at random and placed in paper bags, labeled and transported to the laboratory.

\section{Description of pathogen symptomatology and Isolation:-}

A visual description of the symptomatology was done with the samples of the leaves extracted from the different localities. For the isolation of the fungus was used the blotter method (ISTA, 2012). Small pieces of the infected material were surface disinfested with $2 \%$ sodium hypochlorite and placed them into Petri dishes ( 5 samples/plate) containing 3 blotting disks moistened in sterile distilled water and incubated for 8-10 days at room temperature $\left(25^{\circ} \mathrm{C}+1{ }^{\circ} \mathrm{C}\right)$ at 12 hours light/dark regime.

\section{Morphological characterization of fungal structures:-}

Fungal structures of taxonomic value, such as mycelial type and color, number of septa and length of conidia, as well as the characteristics of the conidiophores were observed and described. The fungus was identified in its natural substrate by the reproductive structures (conidia) observed with a stereoscopic (20x) and microscope (40x). Identification manuals were used for identification of the species (Ellis, 1992a; Ellis, 1993b; Mew and González 2002; ISTA, 2012).

Analysis of variance and a correlation test was used to determine the frequency of the fungus in the different localities.

\section{Results and Discussion:-}

Description of the symptomology of infected leaves:-

Symptoms on leaves were presented as oval-to-circular tanned spots, 3 to $10 \mathrm{~mm}$ in diameter, which then became grayer to white with a narrow dark brown border.

\section{Morphological characterization of the fungus $A$. padwickii:-}

Samples examined on blotting paper with the help of the stereoscope show the growth habit of the fungus as conidia that grow solitary in short conidiophores arising directly from the substrate or in conidiophores between soft fluffy white mycelia.

The conidium at the beginning are sub hyaline and later acquires a straw to brown color, darker than the mycelium with a prominent appendix. Observations under the microscope (40x) show conidia (3-5 septa), often constricted in the celled with conical basal cells and long peaks $(95-170 \mu \mathrm{m} \times 11-20 \mu \mathrm{m})$ (Fig. 1). These morphological 
characteristics coincide with that described for A. padwickii by Ou (1985), Ellis (1992a), Ellis (1993b), Mew and González (2002), ISTA (2012).

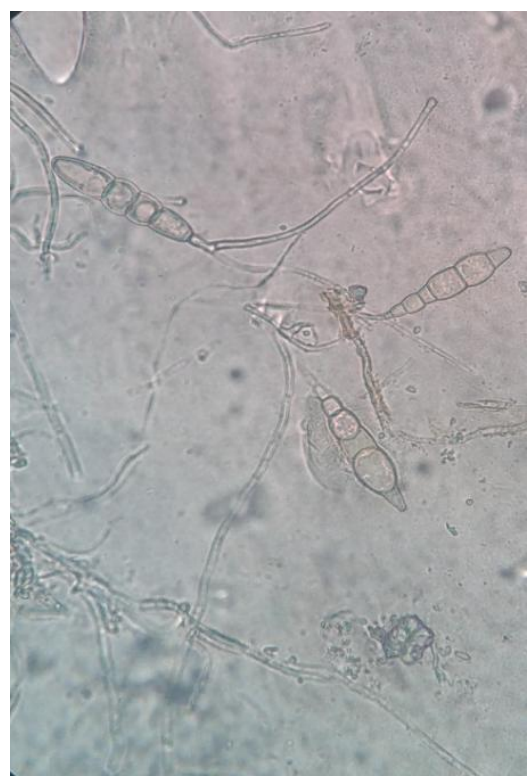

Fig.1:-Conidia of the fungus Alternaria padwickii (40x)

Prevalence of Alternaria padwickii in three rice producing regions:-

The fungus was found in the three localities evaluated in the 2014/2015 rice crop season, Departments of Itapúa, Misiones and Caazapá (Fig.2).

The means presented significant differences in the analysis of variance; statistically the presence of A. padwickii in the department of Itapúa was superior to the Department of Caazapá but similar to the average of Misiones. Likewise, the averages of departments of Caazapá and Misiones were similar to each other.

The correlation of the presence of A. padwickii in the three departments evaluated in this study was high (0.96), showing that this species of Alternaria has a high occurrence in the main rice producing regions in Paraguay.

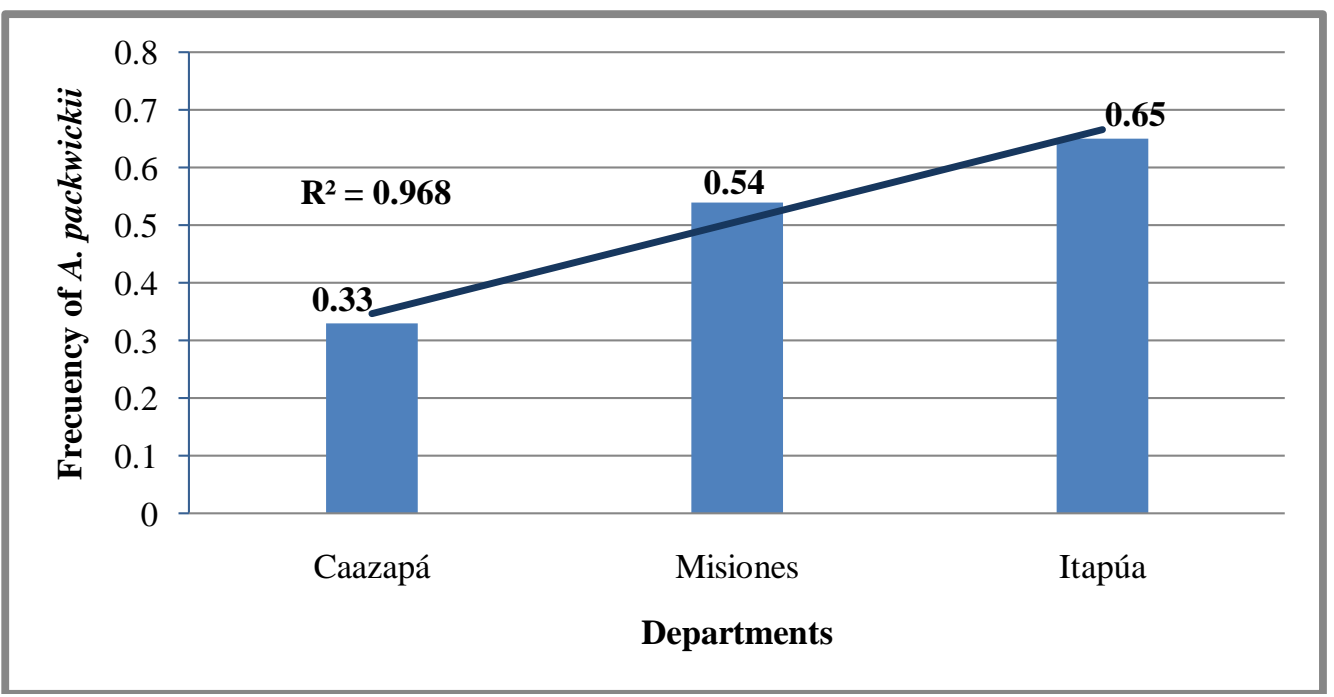

Fig.2:- Frequency of $A$. padwickii in three departments.

Gutiérrez (2010), Gutiérrez et al. (2010) mention this fungus as one of the main pathogens causing rice leaf spot at several districts of the province of Corrientes, Argentina. 
Viedma (2010) reported that A. padwickii was present with an average incidence of $18 \%$ on seed collected from the departments of Itapúa, Misiones and Caazapá. Quintana (2013) also reports the presence of this fungus in seed of four rice cultivars of different districts of the mentioned departments. This indicates that the seed contaminated with this fungus could constitute the main source of inoculum for the development of leaf spot of Alternaria on rice crop in Paraguay.

\section{Conclusion:-}

The morphological characteristics of the fungus isolated in rice leaves from the Departments of Itapúa, Misiones and Caazapá in Paraguay correspond to the species of Alternaria padwickii, associated with rice foliar spots.

The correlation of the presence of $A$. padwickii in the three departments was high (0.96), which indicate that this species of Alternaria is presents frequently in the main rice producing regions of Paraguay.

\section{References:-}

1. CAB International 2001. Compendium of Crop Protection $2^{\text {nd }}$ ed. APS Press. CD Room

2. Ellis, M.B. 1993b. More Dematiaceous Hyphomycetes. UK. Commonwealth Mycological Institute.

3. Ellis, M.B.1993a. Dematiaceous Hyphomycetes. UK. Commonwealth Mycological Institute.

4. Gutiérrez, S.A. 2010. Monitoreo de enfermedades en semillas de arroz. Detección, cuantificación y transmisión de Alternaria padwickii y Microdochium oryzae. Tesis Doctoral, Facultad de Ciencias Agrarias, Universidad Nacional del Nordeste. Corrientes Argentina.

5. Gutiérrez, A.S., Reis, E.M., Carmona, M.A. 2010 b. Methods for detection of Alternaria padwickii in rice seed. Journal of Phytopathology 158:523-526.

6. Gutiérrez, S.A., Cundom, M.A., Cabrera, M.A., Lovato, A.D. 2010. Enfermedades foliares del cultivo del arroz. In: XVII Reunión de Comunicaciones Científicas y Técnicas, Corrientes, Argentina.

7. INBIO (Instituto de Biotecnología Agrícola). 2015. Estimación de la superficie, rendimiento y producción de $\begin{array}{llllll}\text { cultivos de } & \text { y } & \text { y } & \text { otros. } & \text { Disponible }\end{array}$ http://www.inbio.org.py/biblioteca/estimacion_de_superficies

8. ISTA (International Seed Testing Association). 2012. Detection of Alternaria padwickii on Oryza sativa (Rice). Annexe to chapter 7: Seed Health Testing Methods. Bassersdorf, Switzerland, 2002.

9. Lovato, A., Carmona, M., Gutiérrez, S. 2013. Transmisión de Trichoconiella padwickii a coleóptilos de arroz. Trop. plant pathol., Brasília, 38(4):346-348

10. Lovato, A.; Carmona, M.; Gutiérrez, S. 2011. Ubicación de Alternaria padwickii en semillas de arroz. In: II Congreso Argentino de Fitopatología, Resumen. Mar del Plata Argentina. AAF. p. 259

11. MAG (28 de agosto 2014). Mejor comportamiento productivo en arroz y sésamo, zafra 2013/2014 obtenido de http//www.mag.gov.py/index-noti.php?pag=not ver php \&tit=boletín\%20informativo...idex=9880922.

12. Mathur, S.B., Mallya, J.I., Neergaard, P. 1972. Seed-borne infection of Trichoconis padwickii in rice, distribution and damage to seeds and seedlings. Proceedings of the International Seed Testing Association 37:803-810.

13. Mew, T.W.; Misra, J.K. (Eds.). 1994. A Manual of Rice Seed Health Testing. IRRI. Manila Filipinas.

14. Mew, T.W., González, P. 2002. A Handbook of Rice Seed-borne Fungi. IRRI, Los Baños, Philippines, 83 p.

15. Ou, S.H. 1985. Rice Diseases. 2nd Edition. UK. Commonwealth Mycological Institute

16. Quintana, L., Bogado, N. 2013. Studies on seed-borne fungi in four rice cultivars in Paraguay. Acta Phytopathologica Sinica. Vol.43-Supplement, 2013 ISNN 412-0913.

17. Quintana, L., Arriola, M., Gutiérrez, SA., Morínigo, K. 2015 a. Detección de Alternaria padwickii en hojas de arroz en el Departamento de Itapúa. 1er Congreso de Ciencias Agrarias. IPTA. Resúmenes- CD.

18. Quintana, L., Arriola, M., Gutiérrez, SA; Morínigo, K. 2015b. Prevalencia de Alternaria padwickii en el cultivo de arroz en los Departamentos de Itapúa, Misiones y Caazapá. 1er Congreso de Ciencias Agrarias. IPTA. Resúmenes- CD.

19. Ramírez, H. 2009. Situación y Perspectivas del cultivo de arroz en el Paraguay. IV Simposio de Arroz, Asociación de Productores de Arroz de Itapúa. Carmen del Paraná, Itapúa, Py.

20. Richardson, M.J. (1990). An annotated list of seed-borne diseases. 4th ed. Zurich CAB/CMI, 320 p. (Phytopahological Papers 23).

21. Viedma, L. 2010. Evaluación de la sanidad de semilla del arroz en el Paraguay. Revista del Saber Académico. 4(4):25-32.

22. Webster, R.K.; Gunnell, P.S.1992. Compendium of rice diseases. St. Paul. American Phytopalogical Society. 